\title{
PRESENCE OF ACAPOETA TANGANICAE (ACTINOPTERYGII: CYPRINIFORMES: CYPRINIDAE) WITHIN THE LAKE RUKWA CATCHMENT SUPPORTS HISTORIC RIVERINE CONNECTIVITY WITH LAKE TANGANYIKA
}

\author{
Martin J. GENNER ${ }^{1 *}$, George F. TURNER ${ }^{2}$, Alan SMITH ${ }^{3}$, Semvua MZIGHANI ${ }^{4}$, \\ and Benjamin P. NGATUNGA ${ }^{5}$ \\ ${ }^{1}$ School of Biological Sciences, University of Bristol, Bristol, UK \\ ${ }^{2}$ School of Biological Sciences, Bangor University, Bangor, UK \\ ${ }^{3}$ Department of Biological Sciences, University of Hull, Hull, UK \\ ${ }^{4}$ Tanzanian Fisheries Research Institute, P.O. Box 9750, Dar Es-Salaam, Tanzania \\ ${ }^{5}$ Tanzanian Fisheries Research Institute, P.O. Box 9750, Dar Es-Salaam, Tanzania
}

\begin{abstract}
Genner M.J., Turner G.F., Smith A., Mzighani S., Ngatunga B.P. 2015. Presence of Acapoeta tanganicae (Actinopterygii: Cypriniformes: Cyprinidae ) within the Lake Rukwa catchment supports historic riverine connectivity with Lake Tanganyika. Acta Ichthyol. Piscat. 45 (1): 109-112.

Abstract. Freshwater fish biogeography can provide insight into past connectivity of river systems. Here we report the first discovery of the large-bodied cyprinid Acapoeta tanganicae (Boulenger, 1900) inside the Lake Rukwa catchment. Previously this species was thought to be endemic to Lake Tanganyika and immediately proximate sections of connected rivers. This shared distribution supports a scenario of direct connectivity of the two catchments during Holocene high stands of Lake Rukwa.
\end{abstract}

Keywords: biogeography, freshwater vicariance, large 'barbs', freshwater biodiversity, Tanzania

Catchment boundaries can act as significant barriers to dispersal of freshwater fishes, and comparisons of extant aquatic faunas can provide evidence of historic connectivity of long-separated river systems (Burridge et al. 2006). This evidence is useful as it helps us to understand both how species assemblages form, and the effects of longterm population separation on phenotypic diversification. Biogeographic patterns have been particularly insightful for our understanding of the role of palaeodrainage changes in assembling fish communities in Africa, where these processes have often been speculated upon, but typically require further evidence (Beadle 1974, Banister and Clarke 1980).

Lake Rukwa is a large endorheic lake in the western arm of great east African Rift Valley, and has been designated a distinct freshwater ecoregion within Africa (Thieme et al. 2005, Abell et al. 2008). In 1996, the lake was $\sim 165 \mathrm{~km}$ long, $\sim 37 \mathrm{~km}$ wide and maximally $14 \mathrm{~m}$ deep (Thevenon et al. 2002), but it has fluctuated substantially over the last 22000 years (Nicholson 1999, Delvaux and Williamson 2008). The lake is fed by multiple tributaries, several of which flow year round. Fossil horizons indicate the lake was $\sim 180 \mathrm{~m}$ above present levels 13 500-9000 years ago, and during that time may have been connected to Lake Tanganyika (Seegers 1996, Cohen et al. 2013).

The Rukwa basin lies at the intersection of four notable ichthyological regions:

- the Chambeshi River / Lake Mweru system that ultimately flows into the Congo,

- the Lake Tanganyika and Malaragasi system that also flows into the Congo,

- the East Coast rivers including the Great Ruaha (a tributary of the Rufiji), and

- the Lake Malawi system, that flows into the Zambezi.

Comparative work on the composition of the Lake Rukwa fish community has given strong indications of direct connections between Rukwa and the Chambeshi, East Coast and Malagarasi systems (Seegers 1996), but only indirect links with Lake Tanganyika via the Malagarasi system. Seegers (1996) concluded the evidence of a direct connection between the Tanganyika and Rukwa fish faunas was questionable, in part because of the absence of typical elements of the Lake Tanganyika endemic fauna, including

\footnotetext{
* Correspondence: Dr Martin J. Genner, School of Biological Sciences, University of Bristol, Bristol BS8 1TQ, UK, phone +44 (117) 394 1182, e-mail:
} (MG)m.genner@bristol.ac.uk, (GFT)george.turner@bangor.ac.uk, (AS) a.smith@hull.ac.uk, (SM) mzighani@yahoo.com, (BPN)bpngatunga@yahoo.co.uk. 
Table 1

Morphology of the two Lake Rukwa specimens of Acapoeta tanganicae

(Accession numbers BMNH 2014.6.25.1-2), the two type specimens collected from the northern end of Lake Tanganyika by J.E.S. Moore (BMNH 1906.9.6.9-10) and six additional Lake Tanganyika specimens in the BMNH collection; Dorsal spines counts made from x-ray images

\begin{tabular}{|c|c|c|c|c|c|c|c|c|c|c|}
\hline \multirow[t]{2}{*}{ BMNH Accession codes } & \multicolumn{2}{|c|}{ 2014.6.25.1-2 } & \multicolumn{2}{|c|}{ 1906.9.6.9-10 } & \multicolumn{2}{|c|}{ 1982.4.13.4815-4816 } & \multicolumn{2}{|c|}{ 1906.9.8.43-44 } & \multicolumn{2}{|c|}{$1955.12 .20 .874-875$} \\
\hline & Rukwa\#1 & Rukwa\#2 & Lectotype & Paralectotype & $\# 1$ & $\# 2$ & $\# 1$ & $\# 2$ & $\# 1$ & $\# 2$ \\
\hline \multicolumn{11}{|l|}{ Measurements [mm] } \\
\hline Standard length & 138.6 & 97.0 & 290.0 & 263.0 & 122.6 & 100.1 & 155.4 & 149.9 & 86.4 & 185.4 \\
\hline Head length & 31.8 & 24.2 & 61.7 & 53.5 & 29.0 & 24.9 & 34.1 & 32.9 & 21.4 & 40.4 \\
\hline Pre-dorsal length & 66.7 & 44.8 & 136.9 & 121.8 & 57.3 & 48.2 & 75.0 & 71.7 & 41.6 & 83.2 \\
\hline Pre-pelvic length & 70.3 & 48.4 & 134.5 & 121.4 & 60.5 & 49.1 & 76.6 & 72.8 & 46.1 & 83.4 \\
\hline Dorsal length & 32.0 & 27.6 & - & 63.3 & 37.4 & 31.3 & 40.1 & 38.0 & 16.9 & 47.8 \\
\hline Pectoral fin length & 28.3 & 19.5 & 53.1 & 48.3 & 24.6 & 19.6 & 27.3 & 28.1 & 15.3 & 31.3 \\
\hline Pelvic fin length & 26.2 & 17.3 & 48.2 & 41.9 & 22.9 & 17.2 & 26.9 & 25.2 & 14.7 & 34.3 \\
\hline Anal fin length & 27.2 & 18.2 & 49.7 & 47.9 & 22.2 & 17.5 & 25.8 & 24.1 & 15.4 & 29.3 \\
\hline Body depth & 36.6 & 26.1 & 69.5 & 68.5 & 36.8 & 28.4 & 44.8 & 38.9 & 22.1 & 51.2 \\
\hline Body width & 19.8 & 13.7 & 49.2 & - & 15.6 & 13.4 & 15.5 & 13.7 & 10.5 & 22.1 \\
\hline Caudal peduncle length & 25.2 & 16.2 & 57.5 & 56.9 & 23.7 & 20.1 & 32.3 & 28.6 & 14.4 & 38.4 \\
\hline Caudal peduncle depth & 15.1 & 11.8 & 32.2 & 28.9 & 13.1 & 10.4 & 16.9 & 16.8 & 9.3 & 19.9 \\
\hline Head depth & 28.3 & 20.7 & 60.6 & 46.6 & 24.1 & 21.3 & 29.9 & 28.6 & 16.2 & 35.8 \\
\hline Snout length & 11.9 & 7.8 & 21.1 & 18.9 & 8.1 & 8.0 & 11.5 & 9.3 & 7.3 & 12.8 \\
\hline Orbit diameter & 6.8 & 5.5 & 13.8 & 13.1 & 8.9 & 7.8 & 11.1 & 11.2 & 6.7 & 12.2 \\
\hline Inter-orbital width & 14.6 & 10.8 & 28.6 & 23.9 & 12.2 & 10.2 & 14.9 & 13.2 & 8.2 & 16.6 \\
\hline Mouth width & 10.3 & 7.4 & 22.4 & 19.6 & 9.3 & 7.6 & 10.7 & 10.3 & 6.0 & 13.8 \\
\hline Lateral line scale count & 61 & 57 & 68 & 63 & 72 & 62 & 65 & 61 & 62 & 66 \\
\hline Dorsal spines & 13 & 13 & 13 & 13 & \# & \# & \# & \# & \# & \# \\
\hline
\end{tabular}

-not measured due to preservation effects, \# not counted.

Table 2

Morphometric measurements of the two Lake Rukwa specimens of Acapoeta tanganicae specimens (Table 1), presented as percentages of body measurements

\begin{tabular}{|c|c|c|c|c|c|c|c|c|c|c|}
\hline \multirow[t]{2}{*}{ BMNH Accession codes } & \multicolumn{2}{|c|}{$2014.6 .25 .1-2$} & \multicolumn{2}{|c|}{ 1906.9.6.9-10 } & \multicolumn{2}{|c|}{$1982.4 .13 .4815-4816$} & \multicolumn{2}{|c|}{$1906.9 .8 .43-44$} & \multicolumn{2}{|c|}{ 1955.12.20.874-875 } \\
\hline & Rukwa\#1 & Rukwa\#2 & Lectotype & Paralectotype & $\# 1$ & $\# 2$ & $\# 1$ & $\# 2$ & $\# 1$ & $\# 2$ \\
\hline Standard length & 138.6 & 97.0 & 290.0 & 263.0 & 122.6 & 100.1 & 155.4 & 149.9 & 86.4 & 185.4 \\
\hline Head length & 31.8 & 24.2 & 61.7 & 53.5 & 29.0 & 24.9 & 34.1 & 32.9 & 21.4 & 40.4 \\
\hline \multicolumn{11}{|l|}{ Percentage of SL [\%] } \\
\hline Pre-dorsal length & 48.1 & 46.2 & 47.2 & 46.3 & 46.7 & 48.1 & 48.3 & 47.8 & 48.1 & 44.8 \\
\hline Pre-pelvic length & 50.7 & 49.9 & 46.4 & 46.2 & 49.4 & 49.1 & 49.3 & 48.6 & 53.3 & 23.4 \\
\hline Dorsal length & 23.1 & 28.5 & - & 24.1 & 30.5 & 31.3 & 25.8 & 25.3 & 19.6 & 25.8 \\
\hline Pectoral fin length & 20.4 & 20.1 & 18.3 & 18.4 & 20.1 & 19.6 & 17.6 & 18.7 & 17.7 & 16.9 \\
\hline Pelvic fin length & 18.9 & 17.8 & 16.6 & 15.9 & 18.7 & 17.2 & 17.3 & 16.8 & 17.0 & 18.5 \\
\hline Anal fin length & 19.6 & 18.8 & 17.1 & 18.2 & 18.1 & 17.5 & 16.6 & 16.1 & 17.8 & 15.8 \\
\hline Body depth & 26.4 & 26.9 & 24.0 & 26.0 & 30.0 & 28.3 & 28.8 & 25.9 & 25.6 & 27.6 \\
\hline Body width & 14.3 & 14.1 & 17.0 & - & 12.7 & 13.4 & 10.0 & 9.1 & 12.1 & 11.9 \\
\hline Caudal peduncle length & 18.2 & 16.7 & 19.8 & 21.6 & 19.4 & 20.1 & 20.8 & 19.1 & 16.7 & 20.7 \\
\hline Caudal peduncle depth & 10.9 & 12.2 & 11.1 & 11.0 & 10.7 & 10.3 & 10.9 & 11.2 & 10.8 & 10.7 \\
\hline \multicolumn{11}{|l|}{ Percentage of HL [\%] } \\
\hline Head depth & 89.0 & 85.5 & 98.2 & 87.1 & 83.1 & 85.6 & 87.7 & 87.0 & 75.7 & 88.5 \\
\hline Snout length & 37.4 & 32.2 & 34.2 & 35.3 & 27.9 & 32.2 & 33.7 & 28.4 & 34.1 & 31.7 \\
\hline Orbit diameter & 21.4 & 22.7 & 22.4 & 24.5 & 30.7 & 31.5 & 32.6 & 34.1 & 31.1 & 30.3 \\
\hline Inter-orbital width & 45.9 & 44.6 & 46.4 & 44.7 & 42.1 & 41.0 & 43.7 & 40.2 & 38.6 & 41.1 \\
\hline Mouth width & 32.4 & 30.6 & 36.3 & 36.6 & 32.2 & 30.6 & 31.3 & 31.5 & 28.0 & 34.0 \\
\hline
\end{tabular}

- cannot be measured due to preservation effects. 
large-bodied cyprinids of the genera Barbus (now Labeobarbus) and Varicorhinus. However, evidence of direct historical faunal connectivity between the two, comes from the presence of fossil gastropod and ostracode genera otherwise endemic to Lake Tanganyika (Cohen et al. 2013).

Here we contribute additional evidence of a connection between Lake Tanganyika and Rukwa by reporting the discovery of the large-bodied cyprinid fish Acapoeta tanganicae (Boulenger, 1900) in the Lake Rukwa catchment. The genus Acapoeta is currently considered monotypic (Eschmeyer 2014), but has received little attention since it was first proposed (Cockerell 1910) to recognise the similarities of $A$. tanganicae with Asian species of the genus Capoeta, and its distinctiveness from African Varicorhinus. Acapoeta lacks a fleshy lower lip, having instead a straight horny rim, distinguishing it from species of the genera Garra and Labeo. Varicorhinus have a similar horny lower jaw, and so do some specimens of Labeobarbus (formerly 'large' Barbus), notably some L. johnstonii, but all the species of these genera recorded from Tanzanian waters have lateral line scale counts in the range of 21-44, compared to published records of 62-72 for Acapoeta (see Eccles 1992, Table 1). Two specimens were caught on 1 September 2012 in pools of a tributary of the River Songwe $\left(8.90^{\circ} \mathrm{S}, 33.33^{\circ} \mathrm{E}\right)$ using $10 \mathrm{~mm}$ stretched-mesh gillnets. Our specimens measured 138.5 and $97.05 \mathrm{~mm}$ SL (Fig. 1, Tables 1-2). The horny lower jaw rim was consistent with identification as Acapoeta, and the high lateral line counts, namely 57 and 61, were well outside the range for Varicorhinus and Tanzanian Labeobarbus, and close to that reported for the few specimens of Acapoeta previously examined. Acapoeta tanganicae is reported to be common around the rocky shorelines and rapids of inflowing rivers into Lake Tanganyika (Eccles 1992), where it feeds upon epilithic algae (Takamura 1994), and it has until now been considered endemic to Lake Tanganyika and immediately proximate rivers. It has not been recovered in previous comprehensive reviews of the Lake Rukwa catchment fishes (Ricardo 1939, Seegers 1996).

We must consider whether the species could have been deliberately introduced into Lake Rukwa from Lake Tanganyika. Currently only one species is known to have been introduced into Lake Rukwa, a tilapiine - the Singida tilapia, Oreochromis esculentus (Graham, 1928), from northern Tanzania (Seegers 1996). A second tilapiine-the redbreast tilapia, Coptodon rendalli (Boulenger, 1897), is also suspected to have been introduced (Seegers 1996), although there is no conclusive evidence that the species is not native to the Rukwa catchment, while it is indigenous to neighbouring Congo and Lake Malawi catchments. On balance, given the absence of any records of cyprinid translocations in the region, and that fish introductions in Tanzania have historically been restricted to high-value large-bodied tilapiine cichlids, it seems most parsimonious that the presence of $A$. tanganyicae in Lake Rukwa is natural, and been overlooked due to an intrinsic low abundance.

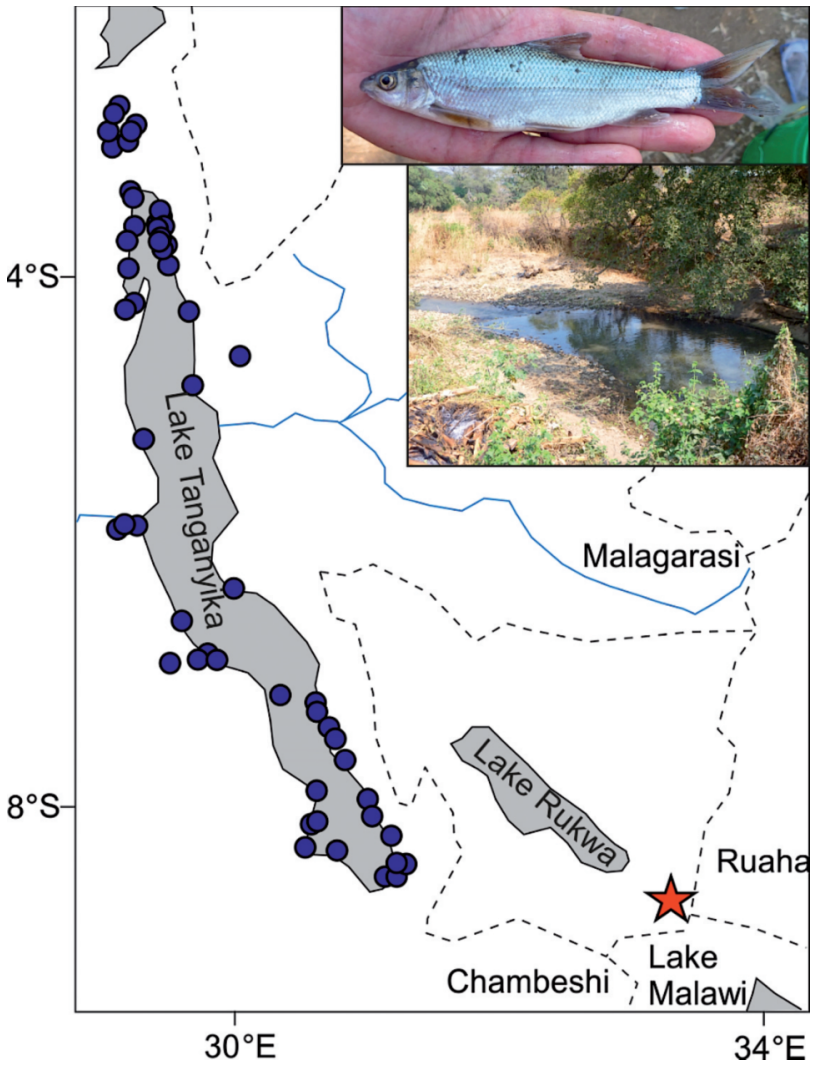

Fig. 1. Records of Acapoeta tanganicae (A): A red star indicates the presently described new capture locality in a pool (B) within a tributary of the Songwe River in the Lake Rukwa catchment; Blue dots indicate 78 capture records from FishBase (Froese and Pauly 2014), all in the Lake Tanganyika catchment; Dashed lines indicate catchment boundaries, only river drainages surrounding the Lake Rukwa basin are labelled

There is currently no published evidence that the species is part of the upstream Malagarasi fauna (Eccles 1992, Seegers 1996, De Vos et al. 2001). Thus, assuming the colonisation of the Rukwa catchment was natural, the evidence is most consistent with a direct faunal connection to the main body of Lake Tanganyika. A plausible colonisation route is via the Nkamba and lower Ifume River spillway, last connected during Holocene high stands of Lake Rukwa (Cohen et al. 2013). Assuming that A. tanganicae colonised Lake Rukwa during these spillover events, then the species must have persisted in the basin during subsequent periods of extreme desiccation that eliminated much of the aquatic diversity, including endemic species of gastropods and ostracodes (Cohen et al. 2013). Whether such refugia persisted in the catchment during drought periods is unknown, partly due a lack of knowledge regarding the timescales of colonisation by the extant fauna as a whole. Molecular time-tree investigations aimed at determining the period of separation of the Lake Rukwa and Lake Tanganyika populations may provide further insight. To date, the only phylogenetic investigations of indigenous Lake Rukwa fish are limited to 
cichlids of the genus Astatotilapia, which indicate at least two colonisations of the basin have taken place (Nagl et al. 2000, Verheyen et al. 2003), but the source locations and timings of colonisation remain unclear.

\section{ACKNOWLEDGEMENTS}

This work was funded by a Royal Society-Leverhulme Trust Africa Award. We thank colleagues at TAFIRI for fieldwork assistance, and $\mathrm{Mr}$ James Maclaine of the Natural History Museum, London, England, for providing access to the type specimens.

\section{REFERENCES}

Abell R., Thieme M.L., Revenga C., Bryer M., Kottelat M., Bogutskaya N., Coad B., Mandrak N., Contreras Balderas S., Bussing W., Stiassny M.L.J., Skelton P., Allen G.R., Unmack P., Naseka A., Ng R., Sindorf N., Robertson J., Armijo E., Higgins J.V., Heibel T.J., Wikramanake E., Olson D., López H.L., Reis R.E., Lundberg J.G., Sabaj Pérez M.H., Petry P. 2008. Freshwater ecoregions of the world: A new map of biogeographic units for freshwater biodiversity conservation. BioScience 58 (5): 403-414. DOI: 10.1641/B580507

Banister K.E., Clarke M.A. 1980. A revision of the large Barbus (Pisces, Cyprinidae) of Lake Malawi with a reconstruction of the history of the southern African Rift Valley lakes. Journal of Natural History 14 (4): 483-542. DOI: $10.1080 / 00222938000770421$

Beadle L.C. 1974. The inland waters of tropical Africa. An introduction to tropical limnology. Longman Group, London, UK.

Burridge C.P., Craw D., Waters J.M. 2006. River capture, range expansion, and cladogenesis: the genetic signature of freshwater vicariance. Evolution 60 (5): 1038-1049. DOI: $10.1111 / j .0014-3820.2006 . t b 01181 . x$

Cockerell T.D.A. 1910. The scales of African cyprinid fishes with a discussion of related Asiatic and European species. Proceedings of the Biological Society of Washington 23: 141-153.

Cohen A.S., Van Bocxlaer B., Todd J.A., McGlue M., Michel E., Nkotagu H.H., Grove A.T., Delvaux D. 2013. Quaternary ostracodes and molluscs from the Rukwa Basin (Tanzania) and their evolutionary and paleobiogeographic implications. Palaeogeography, Palaeoclimatology, Palaeoecology 392: 79-97.

DOI: $10.1016 /$ j.palaeo.2013.09.007

De Vos L., Seegars L., Taverne L., Thys Van Den Audernaerde D. 2001. L'ichtyofaune du bassin de la Malagarazi (système du lac Tanganyika): une synthèse de la connaissance actuelle. Annales du Musee royal de l'Afrique Centrale, Série Zoology 2001 (285): 117-152.
Delvaux D., Williamson D. 2008. Interactions between Great Lakes level change, tectonics and volcanism in the Rungwe Volcanic Province, SW highlands of Tanzania. Bulletin des Séances de l'Académie Royale des Sciences d'Outre-Mer 54 (?): 577-600.

Eccles D.H. 1992. Field guide to the freshwater fishes of Tanzania. FAO, Rome

Eschmeyer W.E. (ed.) 2014. Catalogue of fishes. Online version. California Academy of Sciences, San Francisco, CA, USA. [Accessed 25 June 2014.]

Froese R., Pauly D. (eds.) 2014. FishBase. [version 04/2014] http://www.fishbase.org

Nagl S., Tichy H., Mayer W.E., Takezaki N., Takahata N., Klein J. 2000. The origin and age of haplochromine fishes in Lake Victoria, East Africa. Proceedings of the Royal Society of London, Series B: Biological Sciences 267 (?): 1049-1061.

DOI: $10.1098 / \mathrm{rspb} .2000 .1109$

Nicholson S.E. 1999. Historical and modern fluctuations of lakes Tanganyika and Rukwa and their relationship to rainfall variability. Climatic Change 41 (1): 53-71.

DOI: $10.1023 / \mathrm{A}: 1005424619718$

Ricardo C.K. 1939. The fishes of Lake Rukwa. Journal of the Linnean Society of London, Zoology 40 (275): 625-657. DOI: $10.1111 / j .1096-3642.1939 . t b 01695 . x$

Seegers L. 1996. The fishes of the Lake Rukwa drainage. Vol. 278. Annalen; Zoologische wetenschappen. Koninklijk Museum voor Midden-Afrika, Tervuren, Belgium.

Takamura K. 1984. Interspecific relationships of aufwuchseating fishes in Lake Tanganyika. Environmental Biology of Fishes 10 (4): 225-241.

DOI: $10.1007 / \mathrm{BF} 00001476$

Thevenon F., Williamson D., Taieb M. 2002. A 22 kyr BP sedimentological record of Lake Rukwa ( $8^{\circ} \mathrm{S}, \mathrm{SW}$ Tanzania): environmental, chronostratigraphic and climatic implications. Palaeogeography, Palaeoclimatology, Palaeoecology 187 (3-4): 285-294.

DOI: $10.1016 / \mathrm{S} 0031-0182(02) 00481-9$

Thieme M.L., Abell R., Stiassny M.L.J., Skelton P., Lehner B., Teugels G.G., Dinerstein E., Kamdem-Toham A., Burgess N., Olson D. 2005. Freshwater ecoregions of Africa and Madagascar: A conservation assessment. Island Press, Washington, DC, USA.

Verheyen E., Salzburger W., Snoeks J., Meyer A. 2003. Origin of the superflock of cichlid fishes from Lake Victoria, east Africa. Science 300 (5617): 325-329. DOI: 10.1126/science. 1080699

Received: 1 July 2014 Accepted: 8 February 2015 Published electronically: 31 March 2015 